\title{
Implementasi Pendekatan Saintifik Untuk Meningkatkan Prestasi Siswa dalam Menulis Cerita Pendek
}

\author{
Bambang Panca Syahputra \\ Universitas Muhammadiyah Sumatera Utara \\ Program Studi Pendidikan Bahasa Inggris, Fakultas Keguruan dan Ilmu Pendidikan, Medan \\ benkpanca5@gmail.com
}

\begin{abstract}
Abstrak
Penelitian ini bertujuan untuk meningkatkan prestasi siswa dalam menulis cerita pendek dengan menggunakan pendekatan Saintifik. Penelitian ini dilakukan dengan menerapkan Penelitian Tindakan Kelas (PTK) yang dilaksanakan melalui tahapan perencanaan, tindakan, observasi, dan refleksi. Penelitian berlokasi di FKIP UMSU Medan. Subjek penelitian ini terdiri dari 35 mahasiswa Jurusan Bahasa Inggris semester VII-D tahun akademik 2019/2020. Penelitian ini menggunakan pendekatan kualitatif- kuantitatif untuk mendapatkan data. Pada tes siklus pertama skor rata-rata adalah 74,4 dan pada tes siklus kedua skor rata-rata adalah 87,4. Peningkatan juga dapat dilihat dari persentase kemampuan menulis siswa dalam tes kompetensi pada siklus pertama $60 \%$ (21 siswa) dari jumlah siswa yang memperoleh skor 75. Pada siklus kedua ada 35 siswa mencapai nilai lebih dari 75 dengan persentase 100\% yang berarti seтиa siswa berhasil melebihi standar skor minimum. Ini berarti bahwa penerapan pendekatan Saintifik dalam meningkatkan prestasi siswa dalam menulis cerita pendek berhasil.
\end{abstract}

Kata Kunci: Pendekatan Saintifik, Menulis, Cerita Pendek

\section{PENDAHULUAN}

Menulis sebagai salah satu dari empat keterampilan berbahasa memainkan peran penting dalam pengajaran bahasa. Secara umum, menulis tidak hanya sekedar catatan dari bahasa yang diucapkan, tetapi juga cara bagaimana mengekspresikan ide, perasaan, atau pengalaman. Selanjutnya, menulis adalah cara bagaimana berkomunikasi dengan orang lain melalui sistem penulisan. Kegiatan menulis telah memberikan kontribusi penting bagi kehidupan manusia.
Menurut Harmer (2004: 33) "Menulis sering bermanfat sebagai persiapan untuk beberapa kegiatan lain, khususnya ketika siswa menulis kalimat sebagai pembukaan untuk kegiatan diskusi". Pembelajaran menulis itu dapat membantu siswa untuk melibatkan kegiatan berpikir. Hal ini dapat dilihat dalam aktivitas kehidupan sehari-hari ketika mereka perlu menulis memo, surat, catatan, brosur, artikel, surat lamaran, dan banyak lainnya. Teks tertulis memiliki sejumlah konvensi yang memisahkannya dari berbicara (Harmer 2001: 225). 
Kegiatan menulis khususnya menulis teks sastra di kalangan siswa belum membudaya. Ini bisa dilihat dari kegiatan yang dilakukan oleh siswa yang lebih memilih melakukan kegiatan komunikasi lisan daripada menulis. Hal ini disebabkan oleh kemampuan menulis siswa yang masih rendah terutama dalam menghasilkan tulisan dengan genre fiksi. Siswa mengalami kesulitan dalam menciptakan karakter yang dapat dipercaya, menceritakan kisah yang meyakinkan atau koheren, dan memilih kata-kata yang tepat.

Secara umum, masalah di atas disebabkan oleh dua faktor, yaitu faktor internal dan faktor eksternal. Pertama, faktor internal, yang mencakup kemauan dan kemampuan siswa untuk menulis, masih rendah. Sebagaimana dinyatakan di atas, siswa belum dapat menyampaikan ide-ide cemerlang mereka dan ide-ide dalam tulisan yang baik. Kedua adalah faktor eksternal, yang sangat mempengaruhi prestasi siswa dalam menulis. Salah satu faktor tersebut adalah penggunaan strategi pengajaran konvensional, pengajaran yang berfokus pada guru atau dosen (teacher-centered teaching) sehingga tidak mampu meningkatkan kreativitas siswa dalam menulis. Metode pengajaran tidak mampu meningkatkan kemampuan siswa dalam menulis.

Strategi memiliki peran penting dalam kegiatan pembelajaran karena dapat mendukung proses pembelajaran yang tercermin dalam prestasi siswa setelah mereka dievaluasi. Salah satu strategi yang dapat mengatasi penyelesaian masalah untuk memahami menulis adalah pendekatan Saintifik. Pembelajaran
Saintifik adalah pembelajaran yang menggunakan metode ilmiah, khususnya pembelajaran yang mendorong siswa untuk mengamati, menanyakan, mengeksplorasi, berinteraksi, dan membuat jejaring/ berkomunikasi. Menurut Hosnan dalam Indrilla (2019), pendekatan ilmiah bertujuan untuk melatih siswa dalam mengkomunikasikan ide, terutama dalam menulis. Pendekatan Saintifik juga mengembangkan sikap, pengetahuan, dan keterampilan siswa.

Berdasarkan uraian permasalahan di atas diperlukan suatu strategi pembelajaran yang baik dan menarik untuk meningkatkan kemampuan menulis mahasiswa khususnya dalam karya tulis sastra. Salah satu pendekatan yang dapat diterapkan untuk meningkatkan kemampuan menulis (writing skill) mahasiswa dalam menulis cerita pendek adalah pendekatan Saintifik yang merupakan pendekatan kolaboratif yang berpusat pada mahasisw (studentscentered learning). Mahasiswa berperan aktif dalam mengamati, menanya, mengumpulkan informasi, menalar dan mengkomunikasikan dan dosen berperan sebagai fasilitator. Melalui pendekatan Saintifik akan melatih siswa untuk mengkomunikasikan ide- idenyakhususnya dalam menulis (Hosnan, 2014).

\section{KAJIAN TEORI}

\section{PENDEKATAN SAINTIFIK}

Pendekatan Saintifik adalah strategi pembelajaran yang menggunakan langkah-langkah ilmiah dalam mengajarkan materi pelajaran. Ini memiliki karakteristik melakukan sains 
yang memungkinkan instruktur untuk meningkatkan proses belajar dengan membagi proses pembelajaran menjadi langkah-langkah 5 M (Mengamati, Menanyakan, Mengeksplorasi, Mengasosiasikan dan

Mengkomunikasikan) yang berisi rincian instruksi untuk melakukan pembelajaran siswa

Menurut Hosnan dalam Indrilla (2019), pendekatan Saintifik bertujuan untuk melatih siswa dalam mengkomunikasikan ide, terutama dalam menulis. Pendekatan ilmiah juga mengembangkan sikap, pengetahuan, dan keterampilan siswa. Siswa di pandang sebagai subjek pembelajaran yang harus dilibatkan secara aktif dalam proses pembelajaran.

\section{METODE PENELITIAN}

Penelitian ini dilakukan dengan menggunakan penelitian tindakan kelas (PTK) dengan dua siklus. Setiap siklus terdiri dari: Perencanaan, Tindakan,
Observasi dan Refleksi.

a. Perencanaan, pada tahap ini, peneliti menjelaskan tentang apa (what), mengapa (why), dimana (where), kapan (when), dan bagaimana (how) penelitian dilakukan.

b. Pelaksanaan, pada tahap pelaksanaan, dilakukan kegiatan implementasi atau penerapan perencanaan tindakan.

c. Pengamatan, pada tahap pengamatan terdapat dua kegiatan yang akan diamati, yaitu kegiatan belajar peserta didk dan kegiatan pembelajaran. Pengamatan terhadap proses belajar peserta didik dapat dilakukan sendiri oleh guru pelaksana (peneliti) sambil melaksanakan pembelajaran

d. Refleksi, Tahap ini merupakan inti dari penelitian tindakan kelas dalam mengungkapkan hal-hal yang dirasakan sudah berjalan baik dan bagian yang belum berjalan dengan baik pada saat peneliti mengelola proses pembelajaran.

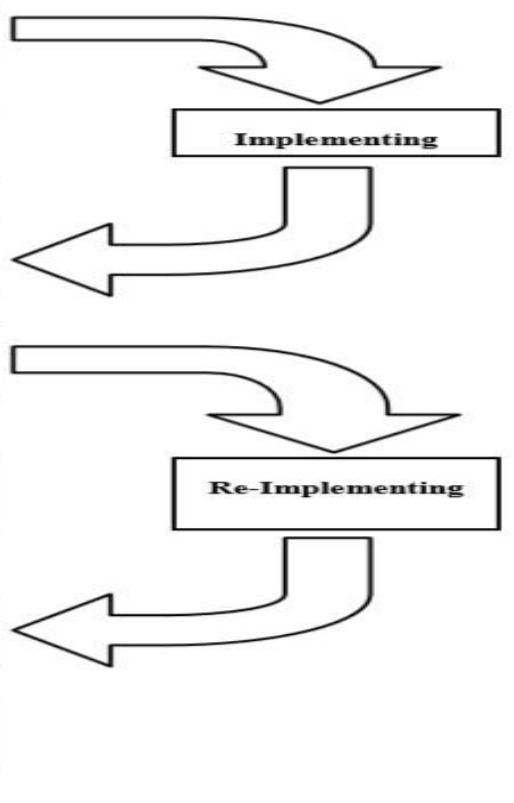




\section{HASIL PENELITIAN}

Tabel 1

Skor Pre-Tes Siswa

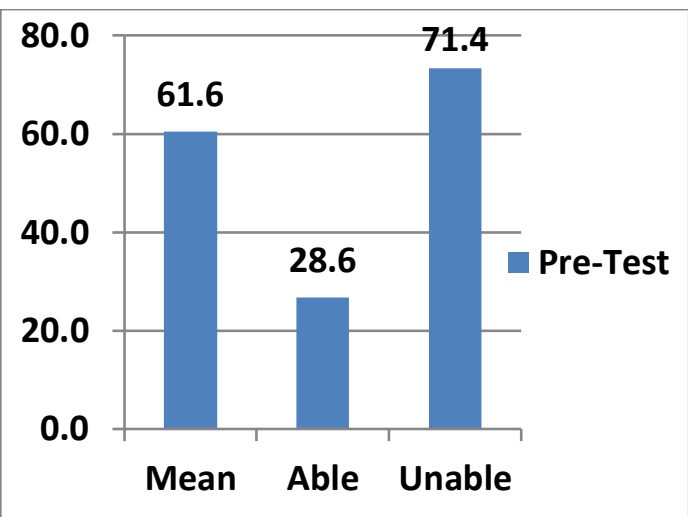

Tabel dan grafik di atas menunjukkan bahwa siswa yang mampu 10 siswa atau $28,6 \%$ dan siswa yang tidak mampu 25 siswa atau $71,4 \%$. Dari data di atas, dapat disimpulkan bahwa siswa di kelas D memiliki kemampuan menulis yang rendah.

Tabel 2

Skor Siswa pada Siklus 1

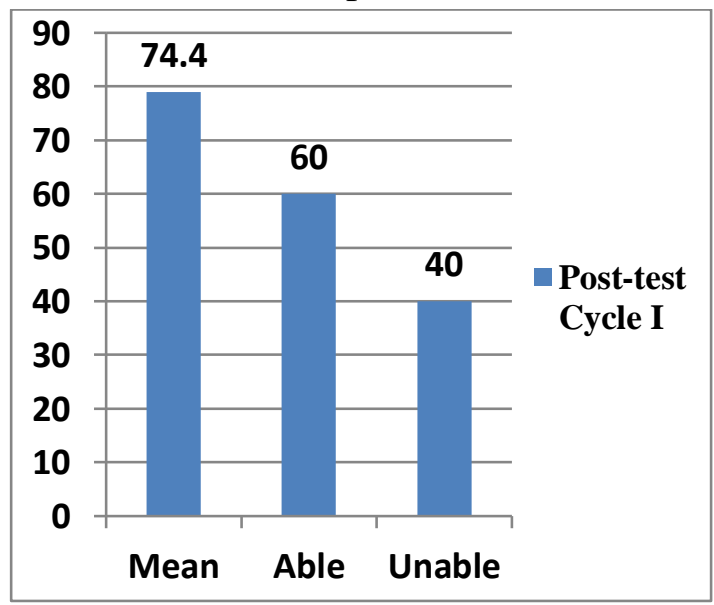

Tabel dan grafik di atas menunjukkan bahwa siswa yang mampu 21 siswa atau $60 \%$ dan siswa yang tidak mampu 14 siswa atau $40 \%$. Peneliti perlu merevisi semua kegiatan dalam siklus II.
Tabel. 3

Skor Siswa pada Siklus II

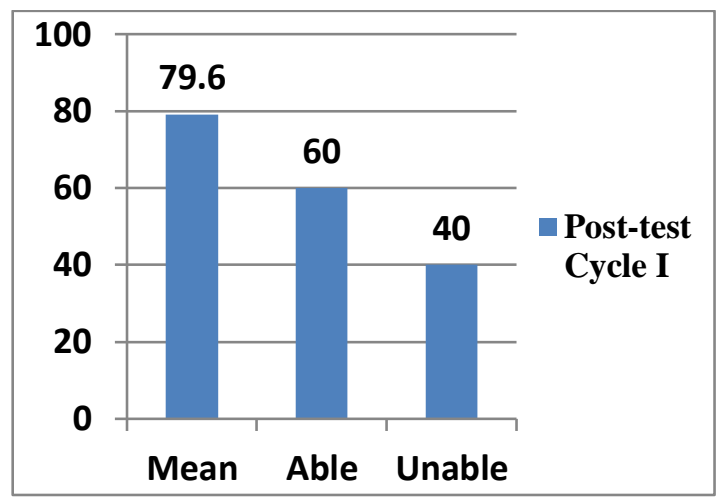

Tabel dan grafik di atas menunjukkan bahwa siswa yang mampu menulis sejumlah 35 siswa atau $100 \%$ dan siswa yang tidak mampu 0 siswa atau $0 \%$. Dari data di atas, dapat disimpulkan bahwa skor siswa pada siklus II telah meningkat secara signifikan.

\section{SIMPULAN}

Terdapat peningkatan pada prestasi siswa dalam menulis cerita pendek dengan menggunakan pendekatan Saintifik. Hal ini bisa dilihat dari nilai siswa rata-rata pre-test pada pertemuan pertama masih rendah, hanya 10 siswa dari 35 siswa yang mendapat nilai 75 . Pada siklus post-test $\mathrm{I}$, terdapat 21 siswa mendapat nilai 75 , dan yang terakhir posttest (siklus II) keseluruhan siswa mencapai standar nilai yang ditentukan. Penerapan pendekatan Saintifik dalam meningkatkan prestasi siswa dalam menulis teks crita pendek berhasil.

\section{DAFTAR PUSTAKA}

Harmer, Jeremy. 2001. The practice of English Teaching: London Pearson Education Limited 
2004. How to teach writing. London: Pearson Education Limited

Hosnan, M.2014. Pendekatan Saintifik dan Kontekstual dalam Pembelajaran Abad 21.Bogor:Ghalia Indonesia

Muslich, M. 2012. Melaksanakan PTK Itu Mudah (Classroom Action Research). Pedoman Praktis bagi Guru Profesional. Jakarta: PT. Bumi Aksara.

Nidya Indrilla. 2018. The Effectiveness of Scientific Approach and Contextual Teaching and Learning Approach in Teaching Writing.Journal Lingua Cultura .p.405-413

Slavin, R.E. 2010. Cooperative Learning Teori, Riset, dan Praktik. Bandung: Nusa Media. 